\title{
A multi-decadal wind-wave hindcast for the North Sea 1949-2014: coastDat2
}

\author{
Nikolaus Groll and Ralf Weisse \\ Institute for Coastal Research, Helmholtz-Zentrum Geesthacht, 21502 Geesthacht, Germany \\ Correspondence to: Nikolaus Groll (nikolaus.groll@hzg.de)
}

Received: 9 May 2017 - Discussion started: 22 June 2017

Revised: 4 October 2017 - Accepted: 3 November 2017 - Published: 4 December 2017

\begin{abstract}
Long and consistent wave data are important for analysing wave climate variability and change. Moreover, such wave data are also needed in coastal and offshore design and for addressing safety-related issues at sea. Using the third-generation spectral wave model WAM a multi-decadal wind-wave hindcast for the North Sea covering the period 1949-2014 was produced. The hindcast is part of the coastDat database representing a consistent and homogeneous met-ocean data set. It is shown that despite not being perfect, data from the wave hindcast are generally suitable for wave climate analysis. In particular, comparisons of hindcast data with in situ and satellite observations show on average a reasonable agreement, while a tendency towards overestimation of the highest waves could be inferred. Despite these limitations, the wave hindcast still provides useful data for assessing wave climate variability and change as well as for risk analysis, in particular when conservative estimates are needed. Hindcast data are stored at the World Data Center for Climate (WDCC) and can be freely accessed using the doi:10.1594/WDCC/coastDat-2_WAM-North_Sea (Groll and Weisse, 2016) or via the coastDat web-page http://www.coastdat.de.
\end{abstract}

\section{Introduction}

Multi-decadal wind-wave hindcasts have become a common tool in supporting the assessment of wave climate variability and change, such as its extremes, trends or seasonal and interannual to decadal variability (e.g. WASA-Group, 1998; Sterl et al., 1998; Cox and Swail, 2001; Weisse and Günther, 2007; Dodet et al., 2010). Data from wind-wave hindcasts are also frequently used in practically oriented applications such as in navigation, shipbuilding, offshore design or strategic planning of logistics for the operation of future offshore wind farms (Weisse et al., 2009, 2015). Further applications comprise studies such as evaluating the impact of waves on sea salt emissions (Neumann et al., 2016) or the evaluation of the potential success or failure of different response strategies to oil pollution (Schwichtenberg et al., 2016). For all these different types of applications long, homogeneous and consistent wind-wave data are needed to derive robust estimates of wind-wave related parameters specific to the problem. Often such information is unavailable from in situ or satellite data alone and multi-decadal wind-wave hindcasts have become a common approach in complementing such analyses.

While formerly wind-wave hindcasts were developed independently using atmospheric forcing available at that time, they nowadays form an integral part of global atmospheric reanalysis systems (e.g. Dee et al., 2011; Chawla et al., 2013). Owing to the limited spatial and temporal resolution of such global reanalyses, there is, however, still a substantial number of regional efforts aiming at higher spatial and temporal resolution. These efforts usually use the traditional approach in which downscaled global reanalysis wind fields are subsequently used to run a wave hindcast system over the reanalysis period or sub-periods within that period (e.g. Charles et al., 2012; Reguero et al., 2012, 2013; Bertin et al., 2013; Ponce de León and Guedes Soares, 2015).

For the North Sea, there presently exist a number of windwave hindcasts covering at least some decades of years. The first of these multi-decadal hindcasts was, to our knowledge, developed within the WASA project (WASA-Group, 1998) while a more recent approach based on the ERA-40 global 
atmospheric reanalysis (Uppala et al., 2005) is described in Reistad et al. (2011). Aiming at a consistent description of met-ocean conditions in the North Sea, Weisse and Günther (2007) developed and described a multi-decadal wind-wave hindcast for the southern North Sea that is part of a comprehensive met-ocean downscaling known as coastDat 1 (Weisse et al., 2009). The latter used the global NCEP/NCAR reanalysis (Kalnay et al., 1996) as boundary conditions and provides a consistent met-ocean data set comprising of regionally downscaled atmospheric (Feser et al., 2001), tide-surge (Weisse and Plüss, 2006) and wind-wave (Weisse and Günther, 2007) conditions from which full met-ocean data are available for every hour over the hindcast period.

Data from coastDat1 have been extensively used for a wide variety of studies. For an overview, see Weisse et al. (2009). While there was and there still is substantial interest in these data, the effort terminated in 2007 when the atmospheric component of the met-ocean hindcast was discontinued and consistent atmospheric data to drive the wind-wave and tidesurge models became unavailable. Up to that time, data from coastDat 1 were used by more than 50 different users with a large variety of applications. About $50 \%$ of the users originated from commercial enterprises, while about $25 \%$ had a more direct scientific interest and another $25 \%$ came from public authorities (Weisse et al., 2015). Because of ongoing interest in both the scientific and the commercial exploitation of the data, eventually a follow-up effort called coastDat2 was initiated. In this effort, upgraded models with higher spatial resolution were used and the wind-wave part, in addition, now also covered the entire North Sea. The atmospheric component of coastDat 2 is described in Geyer (2014). In the following, we describe and evaluate the upgraded wind-wave part (Groll and Weisse, 2016) that is driven by the coastDat2 wind fields (Geyer, 2014).

\section{Model setup}

For the wind-wave hindcast in coastDat 2 the third-generation spectral wind-wave model WAM (WAMDI-Group, 1988; Komen et al., 1996) version 4.5.4 was used. This version represents an update and extension of the WAM cycle 4 used in coastDat1 (Weisse and Günther, 2007), the details of which are described in the WAM documentation available at http://mywave.github.io/WAM/. Apart from some technical changes such as in the $\mathrm{I} / \mathrm{O}$ routines, a major change was introduced by the replacement of the wave dissipation source term with a new version described in Bidlot et al. (2005) and Bidlot et al. (2007).

For the coastDat 2 hindcast, the wave model was used in a nested version with a coarse-grid simulation covering most of the northeast North Atlantic and a finegrid simulation covering the North Sea from $4.75^{\circ} \mathrm{W}$ to $13.25^{\circ} \mathrm{E}$ and from 50.5 to $59.5^{\circ} \mathrm{N}$ (Fig. 1). The grid size of the coarse grid is $0.5^{\circ}$ latitude $\times 0.75^{\circ}$ longitude while

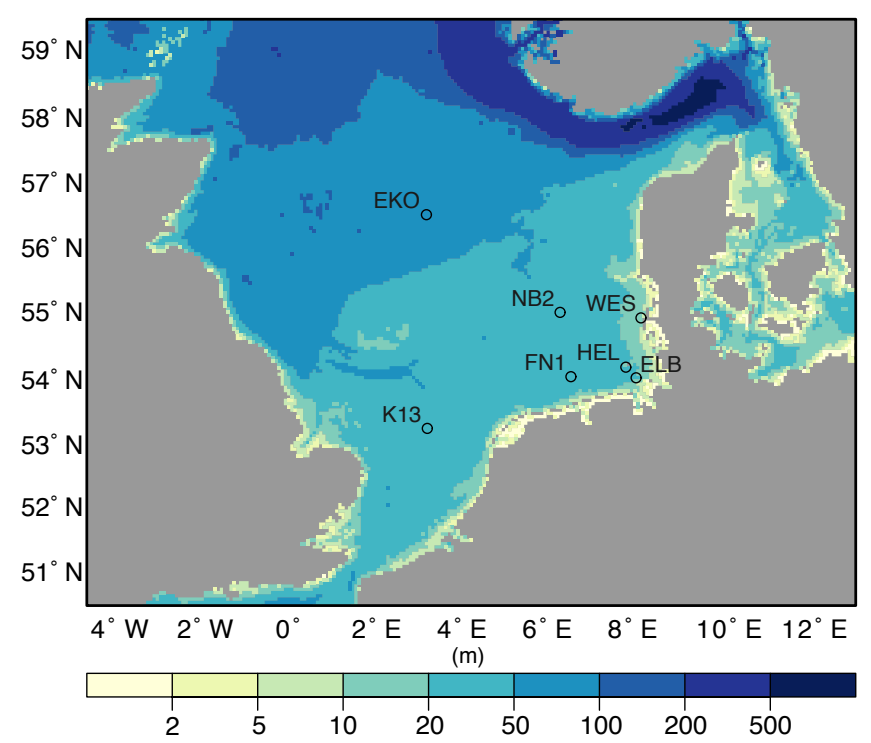

Figure 1. Model domain and bathymetry used for the fine-grid simulation. Colours indicate water depth in metres. Circles mark observational sites used for the model evaluation. For the abbreviations, see Table 1 .

that of the fine grid nested within the coarse grid is $0.05^{\circ}$ latitude $\times 0.075^{\circ}$ longitude. The latter corresponds to a grid spacing of approximately $3 \times 3$ nautical miles.

Wave spectra were computed and discretized using 35 frequencies ranging from approx. 0.042 to $1.067 \mathrm{~Hz}$ and 24 directional bins. The integration time step was set to $3 \mathrm{~min}$, and integrated parameters derived from the wave spectra such as significant wave height, mean period or direction were calculated and stored at every full model hour while wave spectra were kept every $3 \mathrm{~h}$. Boundary conditions were transferred from the coarse to the fine grid every hour using the full modelled wave spectra. For both grids, the model was set up and integrated in shallow-water mode including depth refraction and depth-induced wave breaking. In the coarse-grid simulation, monthly sea ice conditions from the northeast North Atlantic were included to account for the varying fetch arising from variations in sea ice coverage.

\section{External data}

\subsection{Forcing data}

For both the coarse and the fine grid wind-wave simulations near-surface marine wind fields at $10 \mathrm{~m}$ height were used. These were obtained, taking atmospheric stability into account, from the high-resolution regional atmospheric hindcast described in Geyer (2014) as part of coastDat2. For the production of this atmospheric hindcast, the regional atmosphere model COSMO-CLM (Rockel et al., 2008) with a spectral nudging scheme (von Storch et al., 2000) was used to dynamically downscale the global atmospheric conditions 
Table 1. Location and description of in situ measurements used for comparison.

\begin{tabular}{lcccc}
\hline Site & Location & Depth $(\mathrm{m})$ & Time period & Type \\
\hline EKO & $2.6^{\circ} \mathrm{E} / 56.5^{\circ} \mathrm{N}$ & 72 & $1980-1998$ & platform \\
K13 & $3.2^{\circ} \mathrm{E} / 53.2^{\circ} \mathrm{N}$ & 25 & $1980-2008$ & platform \\
NB2 & $6.3^{\circ} \mathrm{E} / 55.0^{\circ} \mathrm{N}$ & 42 & $1993-2012$ & buoy \\
FN1 & $6.6^{\circ} \mathrm{E} / 54.0^{\circ} \mathrm{N}$ & 30 & $2003-2012$ & platform \\
HEL & $7.9^{\circ} \mathrm{E} / 54.2^{\circ} \mathrm{N}$ & 20 & $1989-2012$ & buoy \\
ELB & $8.1^{\circ} \mathrm{E} / 54.0^{\circ} \mathrm{N}$ & 25 & $1990-2012$ & buoy \\
WES & $8.2^{\circ} \mathrm{E} / 54.9^{\circ} \mathrm{N}$ & 14 & $1993-2012$ & buoy \\
\hline
\end{tabular}

given by the driving NCEP/NCAR reanalysis (Kalnay et al., 1996; Kistler et al., 2001). The downscaling was performed for the North Atlantic/ European region and the model was integrated on a rotated grid with a grid size of $0.22^{\circ} \times 0.22^{\circ}$ corresponding to a spatial resolution of about $25 \times 25 \mathrm{~km}$. Atmospheric wind fields to drive the wave model were available and used every model hour. Validation of the atmospheric hindcast is described in Geyer (2014). Compared to the driving global reanalysis an improved representation of marine wind speeds in coastal areas, especially for higher wind speeds, is noted (Geyer et al., 2015). Note that the atmospheric hindcast described in Geyer (2014) ends in 2012, but it is extended to 2014 to guarantee a consistent forcing data for the presented wave hindcast simulation.

For the coarse-grid simulation monthly sea ice concentrations provided by the Hadley Centre Sea Ice and Sea Surface Temperature data set (HadISST1.1, Rayner et al., 2003) were used. The sea ice concentrations had a spatial resolution of $1^{\circ} \times 1^{\circ}$ and were spatially interpolated to the coarse wave model grid. Subsequently in the simulation sea ice was accounted for by treating all model grid points with sea ice concentrations exceeding $50 \%$ as land for the corresponding time steps.

\subsection{Reference data}

A number of in situ wind-wave observations from platforms and buoys in the North Sea originating from different sources were available for validation (Table 1). Basic quality control was applied but no attempt to check homogeneity was done. The data cover different time periods including gaps and differ in their temporal resolution. Because the model output is available only at full model hours, the comparison with observations was limited to data that were measured within \pm 10 min around full hours.

In addition, wind-wave data derived from satellite provided by the merged altimeter wave height database version 11.0 (Queffeulou, 2013) were used. These data originate from the GlobWave project (http://www.globwave.org) and cover the period 1991 to present. The satellite data were co-located with the model data using a co-location criterion of \pm 10 min at which the position of the satellite was matched with the nearest grid point of the wave model.

To compare the wave model results in space and time, data from the ERA-Interim global reanalysis (Dee et al., 2011) spatially interpolated to the coastDat 2 wave model grid were used. More specifically, data from the ocean wave product of ERA-Interim were used, which originates from a comparable version of the wave model WAM. Wave data are available every $6 \mathrm{~h}$ at 00:00, 06:00, 12:00 and 18:00 UTC and at a spatial resolution of $0.75^{\circ}$ latitude $\times 0.75^{\circ}$ longitude. The atmospheric part of the ERA-Interim reanalysis has a 30 min time step and a spatial resolution of about $79 \mathrm{~km}$. For the comparison we use the ERA-Interim data from 1980 to 2014. ERA-Interim used an assimilation scheme, which includes, among others parameters, wind data from satellites and in situ observations. Further, from 1990 onwards, wave spectra in ERA-Interim were adjusted using altimeter data, but no wave buoy data were used in the assimilation scheme (Dee et al., 2011).

In order to avoid biases, only those instances in time are used for comparison for which both observations and hindcast data were simultaneously available. In particular, this results in a comparison of $1 \mathrm{~h}$ and $6 \mathrm{~h}$ data when coastDat2 hindcast/ERA-Interim reanalysis is involved.

\section{Evaluation}

For the evaluation of the wave hindcast the following error metrics were applied: the mean, the standard deviation (SD), the bias, the root mean square error (RMSE), the scatter index (SI) and the correlation coefficient $(r)$. To evaluate the unbiased RMSE the standard deviation of the error (SDE) was used. All measures were calculated for the entire data sets if not stated otherwise. In the following, measures are called errors when simulations are compared with observations and are called differences when the two simulations are compared. Further details of the error metrics can be found in Appendix A.

\subsection{Significant wave height}

Significant wave height (SWH) derived from hindcast data and in situ measurements was compared at seven sites in the North Sea (Fig. 2). Comparison of instantaneous values revealed noticeable scatter between modelled and observed data with biases ranging between about 0 and $0.25 \mathrm{~m}$. Root mean square errors varied between approximately 0.4 and $0.7 \mathrm{~m}$ (Table 2). When distributions were compared, generally a reasonable agreement was inferred for the lower to intermediate percentiles corresponding to wave heights of up to 2-4 m depending on location (Fig. 2). Higher percentiles were generally found to be overestimated in the hindcast data.

To put these findings into perspective, Fig. 2, in addition, shows a corresponding analysis for SWH derived from the 
Table 2. Error metrics for the SWH at seven locations derived from in situ observations (OBS), coastDat2 hindcast (CD2) and ERA-Interim reanalysis (ERAi), for $1 \mathrm{~h}$ (coastDat2) and $6 \mathrm{~h}$ (ERA-Interim) data respectively.

\begin{tabular}{|c|c|c|c|c|c|c|c|}
\hline Name & $\begin{array}{r}\text { Count } \\
\text { CD2 /ERAi }\end{array}$ & $\begin{array}{r}\text { Mean (m) } \\
\text { OBS / CD2 / ERAi }\end{array}$ & $\begin{array}{r}\text { Standard deviation (m) } \\
\text { OBS / CD2 / ERAi }\end{array}$ & $\begin{array}{r}\text { Bias (m) } \\
\text { CD2 / ERAi }\end{array}$ & $\begin{array}{l}\text { RMSE (m) } \\
\text { CD2 / ERAi }\end{array}$ & $\begin{array}{r}\text { Scatter index } \\
\text { CD2 / ERAi }\end{array}$ & $\begin{array}{l}\text { Correlation } \\
\text { CD2/ERAi }\end{array}$ \\
\hline EKO & $51620 / 22589$ & $2.08 / 2.24 / 1.94$ & $1.29 / 1.48 / 1.15$ & $0.16 /-0.14$ & $0.71 / 0.44$ & $0.34 / 0.21$ & $0.88 / 0.95$ \\
\hline K13 & 84744 / 42372 & $1.5 / 1.59 / 1.43$ & $0.92 / 1.08 / 0.86$ & $0.09 /-0.07$ & $0.51 / 0.26$ & $0.34 / 0.17$ & $0.88 / 0.96$ \\
\hline NB2 & $28485 / 5245$ & $1.75 / 1.77 / 1.51$ & $1.11 / 1.23 / 0.91$ & $0.03 /-0.17$ & $0.56 / 0.35$ & $0.32 / 0.21$ & $0.89 / 0.97$ \\
\hline FN1 & $30893 / 4655$ & $1.52 / 1.68 / 1.5$ & $0.97 / 1.16 / 0.9$ & $0.16 /-0.03$ & $0.56 / 0.26$ & $0.37 / 0.17$ & $0.89 / 0.96$ \\
\hline HEL & $46074 / 14208$ & $1.09 / 1.34 / 1.15$ & $0.76 / 0.98 / 0.71$ & $0.25 / 0.06$ & $0.55 / 0.32$ & $0.5 / 0.29$ & $0.87 / 0.91$ \\
\hline ELB & $55190 / 14292$ & $1.04 / 1.18 / 0.92$ & $0.73 / 0.85 / 0.56$ & $0.13 /-0.12$ & $0.44 / 0.32$ & $0.42 / 0.31$ & $0.87 / 0.92$ \\
\hline WES & $43979 / \mathrm{NA}$ & $1.08 / 1.2 / \mathrm{NA}$ & $0.72 / 0.94 / \mathrm{NA}$ & $0.12 / \mathrm{NA}$ & $0.48 / \mathrm{NA}$ & $0.45 / \mathrm{NA}$ & $0.88 / \mathrm{NA}$ \\
\hline SAT & $901451 / 82067$ & $1.76 / 1.94 / 1.69$ & $1.11 / 1.34 / 0.97$ & $0.18 /-0.06$ & $0.64 / 0.36$ & $0.37 / 0.20$ & $0.89 / 0.94$ \\
\hline
\end{tabular}

NA: not available.
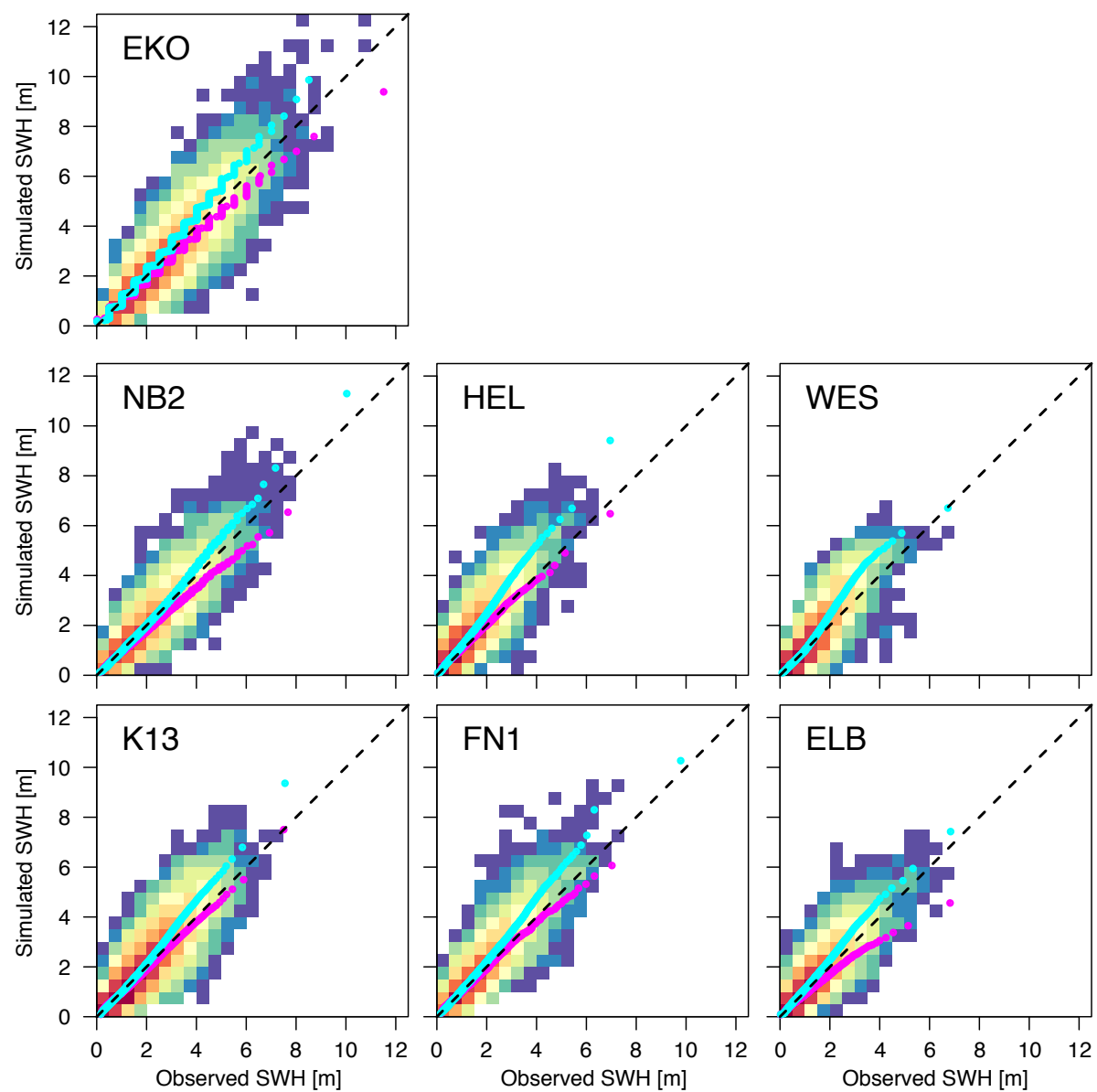

\begin{tabular}{llll|l|l|l|l|l|l|l|l|l|l|l|l}
5 & 10 & 20 & 50 & 100 & 200 & 500 & 10002000 & 5000
\end{tabular}

Figure 2. Scatter and quantile-quantile plot of SWH (in metres) between in situ observation ( $x$-axis) and coastDat2 hindcast data ( $y$-axis). Coloured squares indicate the number of data in each $0.5 \mathrm{~m} \times 0.5 \mathrm{~m}$ bin. Coloured dots represent the percentile values of the quantile-quantile plots between observed and coastDat 2 hindcast (cyan) and between observed and ERA-Interim reanalysis significant wave heights (magenta). Note that the comparison is made for different periods according to data availability (see Table 1). 
ERA-Interim reanalysis. Here, generally, a tendency towards an underestimation of the higher SWHs can be inferred. This feature is most pronounced at near-coastal locations such as at station ELB. An evaluation with a normalized Taylor diagram (Fig. 3) indicates that for both the ERA-Interim and the coastDat 2 SWHs, correlation with observations typically varies around 0.9 with the values being slightly higher for the ERA-Interim reanalysis. The analysis further reveals that the observed SWH variability is somewhat underestimated by the ERA-Interim reanalysis and overestimated in the coastDat 2 data set. The centred root mean square errors are slightly above (below) $0.5 \mathrm{~m}$ for coastDat 2 (ERAInterim). Comparing $6 \mathrm{~h}$ instead of hourly values for the coastDat2 SWHs, no substantial differences for the statistical values used by the Taylor diagram can be found. A more detailed comparison of error statistics for the seven locations is provided in Table 2 .

A spatial comparison of the differences between ERAInterim and coastDat2 SWHs for the common period 19802014 is illustrated in Fig. 4. With the exception of nearcoastal waters, the SWH obtained from the coastDat 2 hindcast is on average higher compared to that from the ERAInterim reanalysis, with increasing differences from south to north. Largest systematic differences of up to $0.6 \mathrm{~m}$ were found off the Norwegian coast. A similar spatial pattern is obtained when root mean square differences are compared. These differences were found to vary between about $0.4 \mathrm{~m}$ in the southern North Sea and more than $0.9 \mathrm{~m}$ in the northern parts of the model domain. When the bias is removed from the root mean square differences, again a similar pattern for the standard deviation of differences with somewhat smaller values compared to the root mean square differences is obtained.

When the spatial comparison is made with the SWHs derived from the GlobWave satellite data set instead of ERAInterim, differences are less distinct but still present (Fig. 5). Similar spatial features but with smaller values are found in the southern North Sea and near the coasts. The latter corresponds to too small wave heights in ERA-Interim when compared to GlobWave data (not shown). Although the underestimation may reach values of up to $0.4 \mathrm{~m}$ on average, the magnitude of the systematic differences between ERAInterim and GlobWave is still smaller than that between the coastDat 2 and the GlobWave data. Note that the robustness of these results is limited, as the number of available satellite data is small. For most of the domain less than 100 colocated data points were available for the comparison. This corresponds to only about $0.1 \%$ of the potentially available hourly values within the period 1992-2014.

To obtain a more robust figure, an additional comparison of co-located data from GlobWave and coastDat2 was made, taking all co-located data irrespective of their location into account. The results are shown in Fig. 6 and corresponding error statistics are presented in Table 2. Altogether, errors statistics obtained and conclusions derived from this exer-

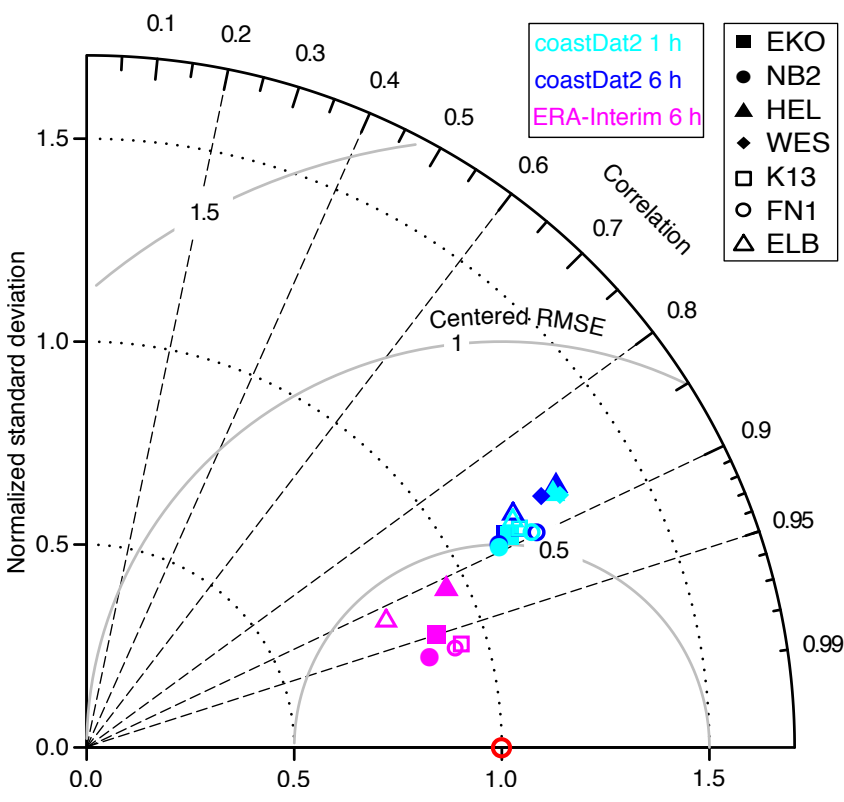

Figure 3. Normalized Taylor diagram from $1 \mathrm{~h}$ (cyan) and $6 \mathrm{~h}$ (blue) coastDat 2 SWHs and from $6 \mathrm{~h}$ ERA-Interim (magenta) SWHs at seven (coastDat2) and at six (ERA-Interim) observational sites. The red circle represents a perfect model compared to the observations.

cise are similar to those based on comparison with in situ observations. Values for bias and RMSE are slightly enhanced compared to those derived from comparison with in situ observations. This can be attributed to the fact that most of the in situ observations were taken in the southern part of the North Sea, where error statistics of the coastDat 2 hindcast are smaller, while the more northern parts with larger errors have a stronger weight in the GlobWave comparison.

\subsection{Wave period}

Different definitions for wave periods are used depending on the specific analysis. Here two of the more frequently used measures are used for comparison with observations: (i) the mean zero crossing period derived from the zerothand second-order moment of the spectrum $\left(T_{\mathrm{m} 02}\right)$ and (ii) the mean wave period (MWP) defined by the ratio of the firstand zeroth-order moment of the spectrum corresponding to the total energy of the wave spectrum (Holthuijsen, 2007). The comparison is made based on the availability of the different data sets.

When observed and hindcast $T_{\mathrm{m} 02}$ periods are compared, an underestimation (overestimation) for short (long) periods can be inferred for most locations (Fig. 7). Deviations are mostly small and typically of the order of $0.5 \mathrm{~s}$, except for the near-shore location WES. Despite the scatter for instantaneous values, hindcast wave periods on average show a good agreement with the observations. The larger deviations occurring at the location WES are probably related to the relatively shallow water depth, which might lead to too small 
(a)

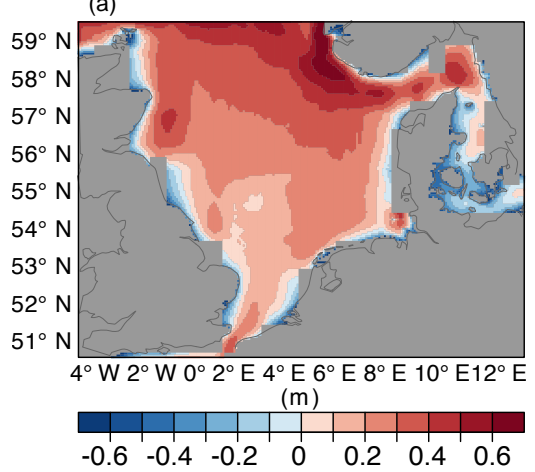

(b)

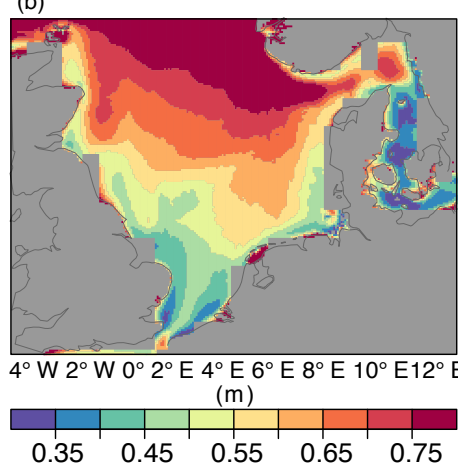

(c)

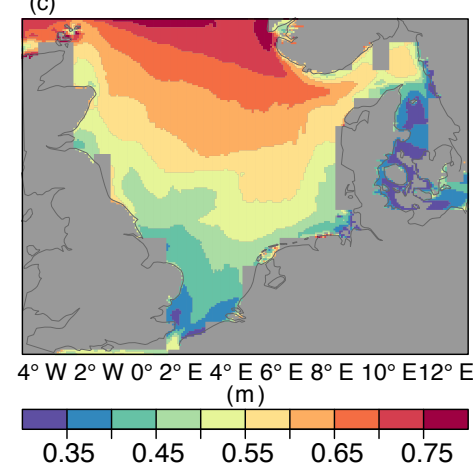

Figure 4. Spatial distribution (in metres) of bias (a), root mean square distance (b) and standard deviation of the error (c) between SWHs derived from the coastDat2 hindcast and the ERA-Interim reanalysis for the period 1980-2014.

(a)

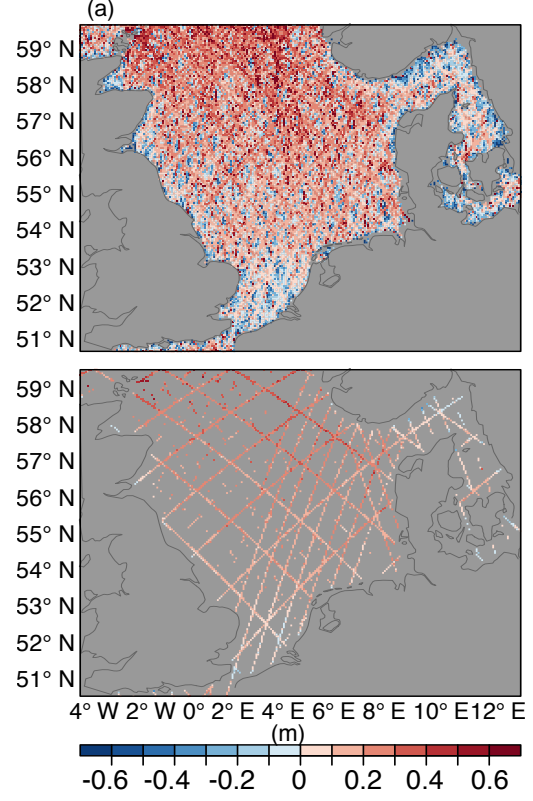

(b)
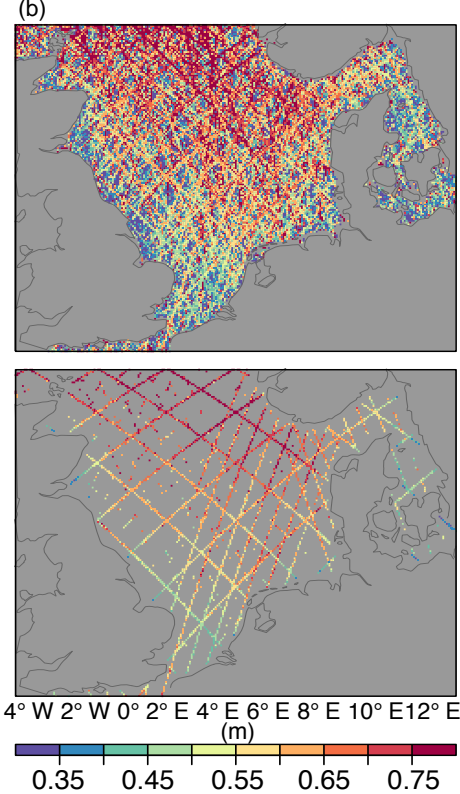

(c)
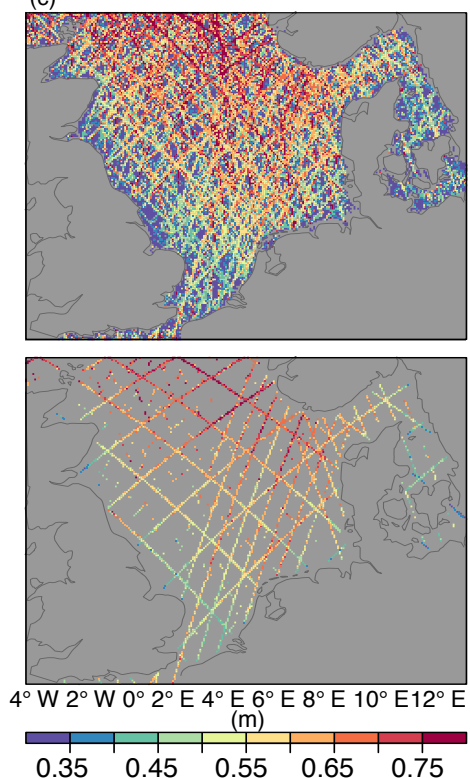

Figure 5. Spatial distribution of bias (a), root mean square error (b) and standard deviation of the error (c) [m] between SWHs from the coastDat2 hindcast and the GlobWave data set for the period 1992-2014 when all available satellite data are used for comparison (top) and when only data with more than 100 flyovers per grid point are used (bottom).

Table 3. Error metrics for the $T_{\mathrm{m} 02}$ period at six locations derived from in situ observations (OBS) and coastDat2 hindcast (CD2) data for hourly values.

\begin{tabular}{lrrrrrrr}
\hline Name & $\begin{array}{r}\text { Count } \\
\text { CD2 }\end{array}$ & $\begin{array}{r}\text { Mean (s) } \\
\text { OBS/CD2 }\end{array}$ & $\begin{array}{r}\text { Standard deviation (s) } \\
\text { OBS/CD2 }\end{array}$ & $\begin{array}{r}\text { Bias (s) } \\
\text { CD2 }\end{array}$ & $\begin{array}{r}\text { RMSE (s) } \\
\text { CD2 }\end{array}$ & $\begin{array}{r}\text { Scatter index } \\
\text { CD2 }\end{array}$ & $\begin{array}{r}\text { Correlation } \\
\text { CD2 }\end{array}$ \\
\hline K13 & 84744 & $4.76 / 4.37$ & $0.91 / 1.21$ & -0.39 & 0.84 & 0.18 & 0.79 \\
NB2 & 28485 & $4.92 / 4.65$ & $1.19 / 1.34$ & -0.27 & 0.87 & 0.18 & 0.79 \\
FN1 & 30893 & $4.72 / 4.51$ & $1.05 / 1.14$ & -0.21 & 0.82 & 0.17 & 0.82 \\
HEL & 46074 & $4.32 / 3.93$ & $0.93 / 1.21$ & -0.30 & 0.81 & 0.19 & 0.78 \\
ELB & 55190 & $4.03 / 3.6$ & $0.92 / 1.12$ & -0.43 & 0.82 & 0.20 & 0.78 \\
WES & 43979 & $4.22 / 3.83$ & $0.89 / 1.48$ & -0.40 & 1.07 & 0.25 & 0.76 \\
\hline
\end{tabular}


Table 4. Error metrics for the MWP at four locations derived from in situ observations (OBS), coastDat2 hindcast (CD2) and ERA-Interim (ERAi) data for $1 \mathrm{~h}$ (coastDat2) and $6 \mathrm{~h}$ (ERA-Interim) data, respectively.

\begin{tabular}{lrrrrrrr}
\hline Name & $\begin{array}{r}\text { Count } \\
\text { CD2/ERAi }\end{array}$ & $\begin{array}{r}\text { Mean (s) } \\
\text { OBS /CD2/ERAi }\end{array}$ & $\begin{array}{r}\text { Standard deviation (s) } \\
\text { OBS /CD2/ERAi }\end{array}$ & $\begin{array}{r}\text { Bias (s) } \\
\text { CD2/ERAi }\end{array}$ & $\begin{array}{r}\text { RMSE (s) } \\
\text { CD2/ERAi }\end{array}$ & $\begin{array}{r}\text { Scatter index } \\
\text { CD2/ERAi }\end{array}$ & $\begin{array}{r}\text { Correlation } \\
\text { CD2/ERAi }\end{array}$ \\
\hline NB2 & $28485 / 5254$ & $5.25 / 6.16 / 5.75$ & $1.23 / 1.54 / 1.2$ & $0.91 / 0.59$ & $1.31 / 0.83$ & $0.25 / 0.16$ & $0.79 / 0.88$ \\
$\mathrm{FN} 1$ & $30893 / 4655$ & $5.11 / 6.14 / 5.75$ & $1.19 / 1.66 / 1.21$ & $1.04 / 0.62$ & $1.41 / 0.8$ & $0.28 / 0.16$ & $0.82 / 0.91$ \\
$\mathrm{ELB}$ & $55190 / 14292$ & $4.32 / 4.99 / 4.96$ & $1.02 / 1.39 / 1.05$ & $0.67 / 0.63$ & $1.08 / 0.87$ & $0.25 / 0.2$ & $0.8 / 0.83$ \\
$\mathrm{WES}$ & $43979 / \mathrm{NA}$ & $4.58 / 5.45 / \mathrm{NA}$ & $1.02 / 1.77 / \mathrm{NA}$ & $0.87 / \mathrm{NA}$ & $1.46 / \mathrm{NA}$ & $0.32 / \mathrm{NA}$ & $0.78 / \mathrm{NA}$ \\
\hline
\end{tabular}

NA: not available.

Table 5. Error metrics for the mean wave direction at three locations derived from in situ observations (OBS), coastDat2 hindcast (CD2) and ERA-Interim (ERAi) data for $1 \mathrm{~h}$ (coastDat2) and $6 \mathrm{~h}$ (ERA-Interim) data, respectively.

\begin{tabular}{lrrrrrrr}
\hline Name & $\begin{array}{r}\text { Count } \\
\text { CD2/ERAi }\end{array}$ & $\begin{array}{r}\text { Mean }\left({ }^{\circ}\right) \\
\text { OBS /CD2/ERAi }\end{array}$ & $\begin{array}{r}\text { Standard deviation }\left({ }^{\circ}\right) \\
\text { OBS/CD2 } / \text { ERAi }\end{array}$ & $\begin{array}{r}\text { Bias }\left({ }^{\circ}\right) \\
\text { CD2/ERAi }\end{array}$ & $\begin{array}{r}\text { RMSE }\left(^{\circ} \text { CD2/ERAi }\right. \\
\text { Ccatter index } \\
\text { CD2/ERAi }\end{array}$ & $\begin{array}{r}\text { Correlation } \\
\text { CD2/ERAi }\end{array}$ \\
\hline NB2 & $28485 / 5254$ & $241 / 233 / 226$ & $99 / 100 / 95$ & $26 / 24$ & $41 / 37$ & $0.17 / 0.15$ & $0.79 / 0.85$ \\
K13 & $84744 / 42372$ & $204 / 205 / 217$ & $113 / 117 / 107$ & $25 / 22$ & $40 / 35$ & $0.20 / 0.17$ & $0.82 / 0.86$ \\
FN1 & $30893 / 4655$ & $254 / 238 / 235$ & $102 / 105 / 97$ & $24 / 26$ & $38 / 38$ & $0.15 / 0.15$ & $0.83 / 0.85$ \\
\hline
\end{tabular}

wave dissipation caused by missing small-scale bathymetric features not resolved at the given spatial resolution of the wave hindcast model.

A spatial comparison of the MWPs from the coastDat2 hindcast and the ERA-Interim reanalysis for the period 1980-2014 is presented in Fig. 8. On average, the coastDat2 hindcast shows longer MWP (up to more than $0.6 \mathrm{~s}$ ) for large areas of the North Sea with the largest differences occurring in the deeper waters in the northeastern part of the model domain. In coastal areas, differences are mostly less pronounced. For the root mean square differences and the standard deviation of the differences, similar spatial patterns can be inferred.

A comparison between $T_{\mathrm{m} 02}$ period measures derived from observations and the coastDat 2 hindcast is presented in Table 3. The MWP measures between observations, coastDat2 hindcast and the ERA-Interim reanalysis are presented in Table 4 . It can be inferred that, compared to observations, $T_{\mathrm{m} 02}$ periods are on average underestimated in the coastDat 2 hindcast while MWPs are on average overestimated. For ERAInterim no $T_{\mathrm{m} 02}$ data were available. MWPs are similarly biased high, although with somewhat smaller values. Variability is generally overestimated in both model simulations with the ERA-Interim errors again being smaller.

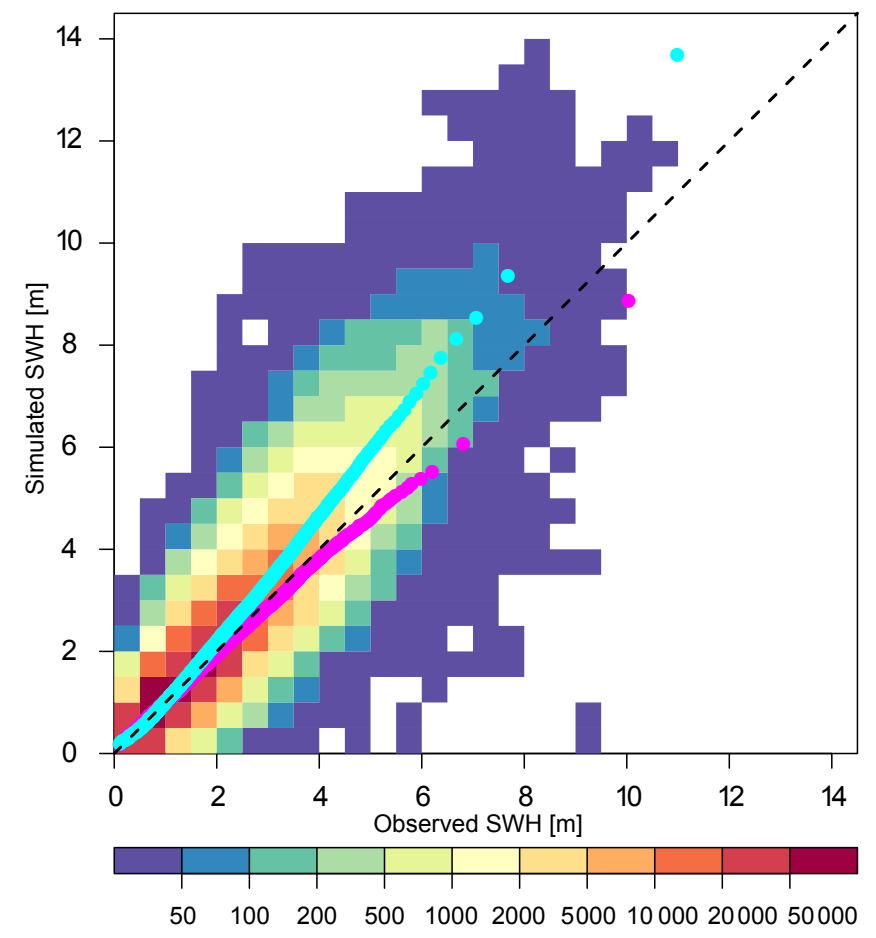

Figure 6. Scatter and quantile-quantile plot of SWH (in metres) between altimeter (GLOBWAVE) observation ( $x$-axis) and coastDat2 hindcast data ( $y$-axis). Coloured squares indicate the number of the data in each $0.5 \mathrm{~m} \times 0.5 \mathrm{~m}$ bin. Coloured dots represent the percentile values of the quantile-quantile plots between observed and coastDat 2 hindcast significant wave heights (cyan) and between observed and ERA-Interim SWH (magenta). 

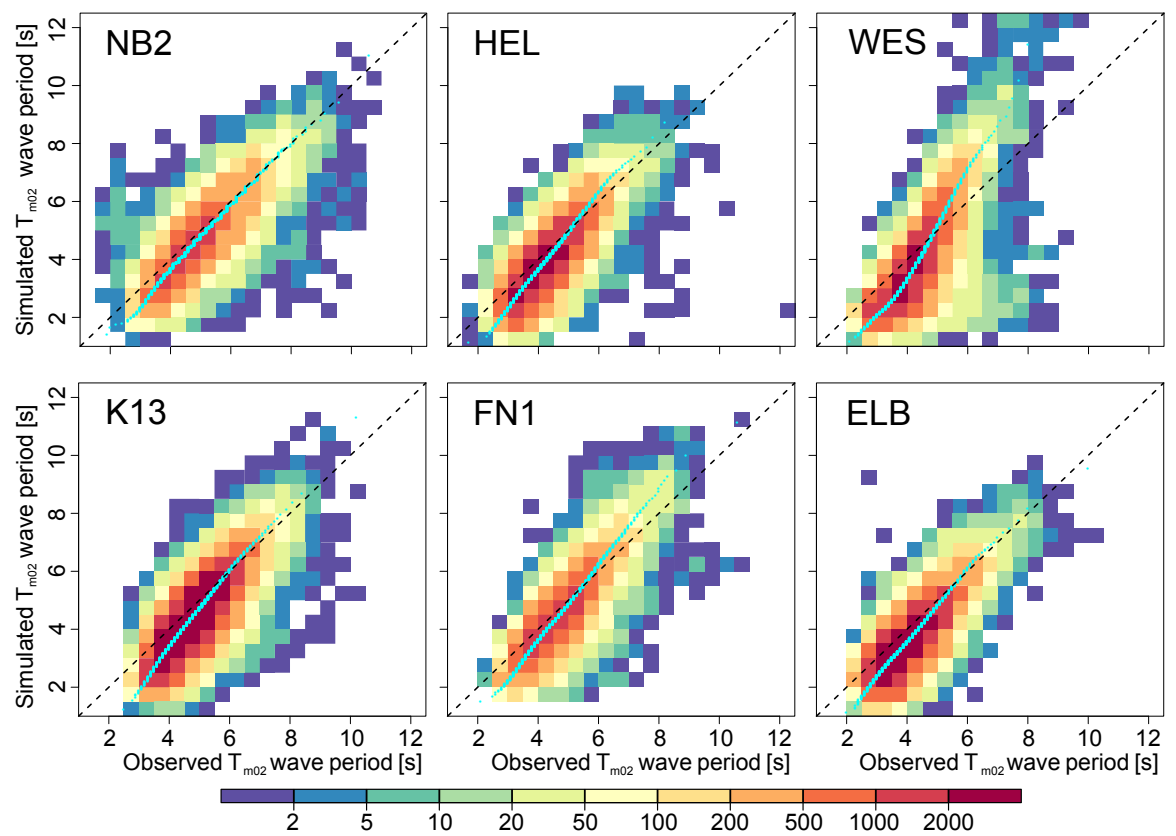

Figure 7. Scatter and quantile-quantile plot of $T_{\mathrm{m} 02}$ wave period (in seconds) between in situ observation ( $x$-axis) and coastDat 2 hindcast data ( $y$-axis). Coloured squares indicate the density of the data in each $0.5 \mathrm{~s} \times 0.5 \mathrm{~s}$ bin. Coloured dots represent the percentile values of the quantile-quantile plots between observed and coastDat 2 hindcast $T_{\mathrm{m} 02}$ (cyan) wave periods. Note that the comparison is made for different periods according to data availability (see Table 1).
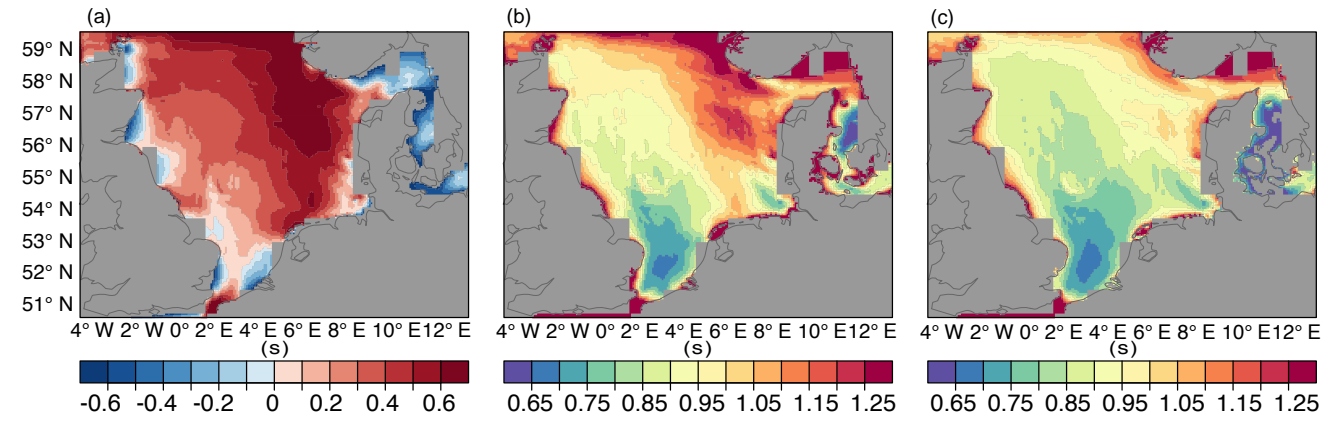

Figure 8. Spatial distribution (in seconds)of bias (a), root mean square error (b) and standard deviation of the error (c), between the mean wave period between from the coastDat2 hindcast and ERA-Interim reanalysis for the period 1980-2014.

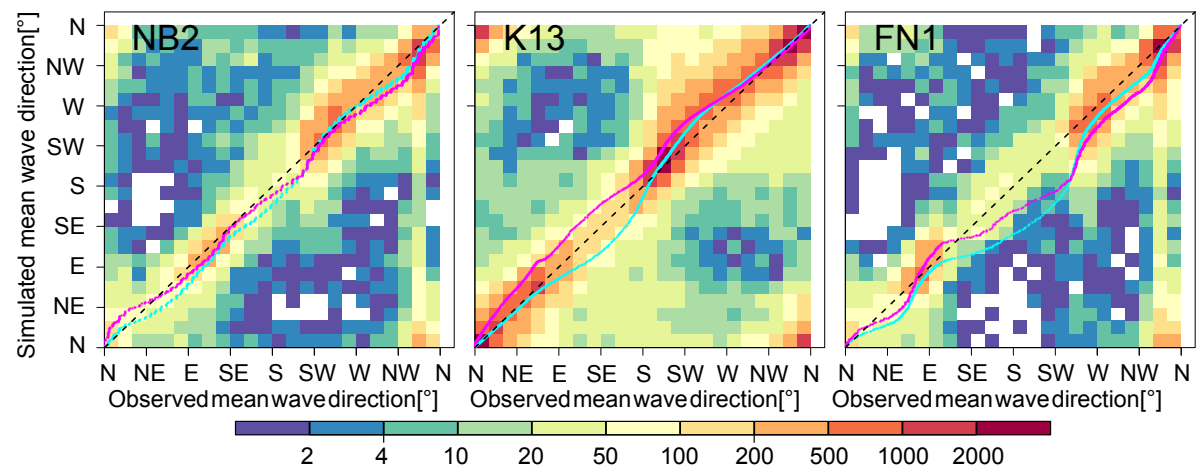

Figure 9. Scatter and quantile-quantile plot of mean wave direction between in situ observation ( $x$-axis) and coastDat2 hindcast data ( $y$-axis). Coloured squares indicate the number of counts in each $15^{\circ} \times 15^{\circ}$ bin. Coloured dots represent the percentile values of the quantile-quantile plots between observed and coastDat2 hindcast mean wave directions (cyan) and between observed and ERA-Interim mean wave directions (magenta). Note that the comparison is made for different periods according to data availability (see Table 1). 


\subsection{Wave direction}

A comparison between mean wave directions derived from coastDat2, ERA-Interim and observations was performed at three locations (Fig. 9). Generally, a good agreement was inferred. At FN1 a more systematic deviation for mean wave directions coming from southerly directions was obtained. Both model data, coastDat 2 and ERA-Interim, show the same systematic error (Table 5). This may point to some bathymetric effects that remain unresolved at the chosen model resolution or to the installation of wave measurements that might be sheltered from certain wave directions.

\subsection{Individual extreme events}

In order to illustrate the amount of agreement and disagreement described above in a more direct and accessible way, modelled and observed wave parameters during an extreme wave event were compared. Here we used the event generated by the extra-tropical storm Britta (31 October 20061 November 2006) which caused some structural damage at the platform FINO1 (Kettle, 2015). Visual inspection of time series of significant wave height, wave periods and direction reveals that while the overall development for the days around the storm is reasonably captured by both the coastDat2 hindcast and the ERA-Interim reanalysis, both data sets substantially underestimate the peak significant wave height that occurred during the storm (Fig. 10).

The underestimation is less severe in the coastDat2 hindcast and substantially more pronounced in the ERA-Interim reanalysis. Inspection of the time series further shows that during less stormy periods ERA-Interim data are generally closer to the observations, while positive systematic errors are obvious for the coastDat 2 hindcast. In detail and for the time series shown, it was found that (i) peak significant wave heights appear to be better represented in the coastDat 2 hindcast while there generally appears to be a too rapid increase towards the extremes, (ii) during times with small wave periods the $T_{\mathrm{m} 02}$ period appears to be reasonable in the coastDat2 simulation while again a too rapid increase towards the extremes is observed, (iii) for the MWP a systematic bias towards too high values is clearly visible that is substantially less pronounced in the ERA-Interim data and (iv) mean wave directions are very well represented in both simulations.

Extreme value analyses are often based on maximum values occurring within an interval for which a given threshold is exceeded. For the analysis, the exact timing of the extreme within this interval is less important. In order to assess the representativeness of such extremes in the modelled data set, we defined the duration of an extreme event as the time period for which the SWH exceeded the 95th percentile of the observed SWH and sampled the maximum SWHs that occurred during that interval from all data sets; that is, the observations, coastDat 2 and ERA-Interim. The analysis was performed exemplary for station FN1. It was
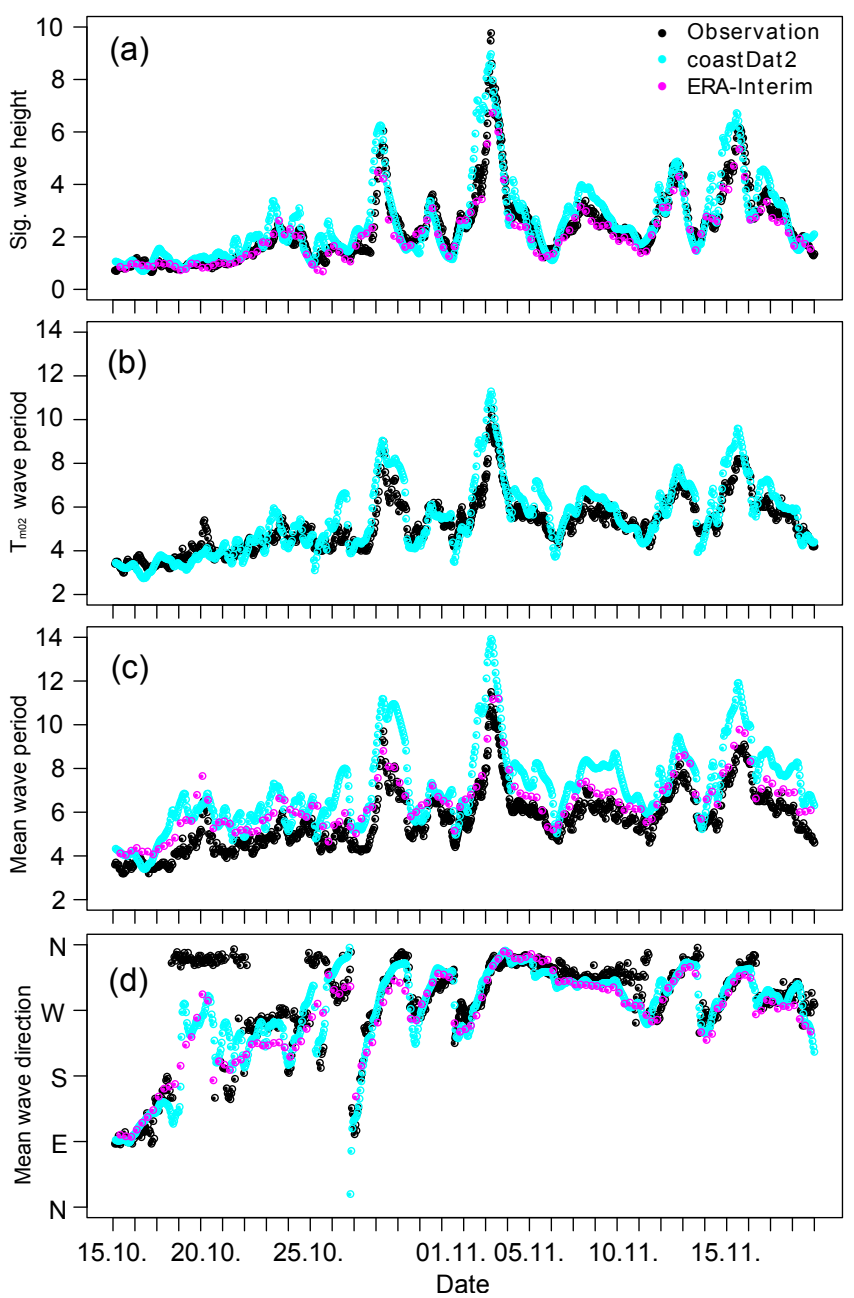

Figure 10. Time series of significant wave height (in metres) (a), $T_{\mathrm{m} 02}$ (in seconds) (b) mean wave period (in seconds) (c) and mean wave direction (in degrees) (d) at FN1 for the period 15 October 2006, 00:00 UTC to 15 November 2006, 00:00 UTC. Observations are shown in black (a-d), the coastDat 2 hindcast is shown in cyan (a-d) and the ERA-Interim data are shown in magenta (a,c,d).

found that coastDat 2 overestimated the observed maximum SWH by $0.38 \mathrm{~m}$ with an RMSE of $1.12 \mathrm{~m}$. ERA-Interim on the other hand underestimated the observed maximum SWH by $-0.63 \mathrm{~m}$ but showed a smaller RMSE of $0.81 \mathrm{~m}$. While the underestimation of ERA-Interim extremes could partly be related to the coarser temporal resolution of $6 \mathrm{~h}$, the result indicates that for extreme value analyses data from coastDat 2 would provide a more conservative estimate.

\section{Data availability}

Wind-wave hindcast data are stored at the World Data Center for Climate (WDCC) and can be freely accessed using the doi:10.1594/WDCC/coastDat-2_WAM-North_Sea (Groll and Weisse, 2016). 


\section{Conclusions}

To our knowledge, the described data set represents the longest regional reconstruction of wind-wave climate for the North Sea based on dynamically downscaled high-resolution atmospheric reanalysis data. It covers more than 60 years and provides hourly integrated wind-wave parameters and spectral wave information every $3 \mathrm{~h}$ at a spatial resolution of approximately 3-by-3 nautical miles.

Altogether, the reconstructed data show a good agreement with observations, although the error metrics for the shorter and coarser ERA-Interim reanalysis show smaller errors for most locations and outperforms the hindcast, especially for open sea areas. Whereas the ERA-Interim wave product underestimates the significant wave height, the coastDat2 hindcast overestimates the wave heights to some extent. This is consistent with marine wind analysis of the forcing data, which showed a slight overestimation of the observed wind speed (Geyer et al., 2015). However, there is some evidence that for extreme conditions and near-coastal locations, the higher temporal and spatial resolution of the presented wave hindcast lead to an added value. Due to the lack of long consistent near-coastal wave observations a detailed analysis of the added value is not possible. Compared to the coastDat 1 wave hindcast (Weisse and Günther, 2007), which ends in 2007, the presented hindcast coastDat 2 shows similar performance with slightly higher values and variability for mean conditions, but less overestimation during extreme events (not shown). One benefit of this coastDat 2 wind-wave hindcast is the extended period for which reconstructed data are available, and the more comprehensive set of wave parameters available (Appendix B). The increased resolution both in space and time does not necessarily lead to improved simulated wave conditions. Despite the limitations of the wave hindcast it is still useful for several applications. The analysis of long-term trend and variability of wave conditions needs long consistent time series as provided by this hindcast. A long-term analysis of the forcing wind fields by Geyer et al. (2015) showed, as other studies, that the wind speed in the North Sea region increased towards the end of the 20th century, with no further increase since then. Kistler et al. (2001) showed that the forcing global reanalysis provides good enough homogeneity to analyse long-term climate trends and variability, especially after 1958. Thus, it can be expected that the wave hindcast provides homogeneity throughout the simulation periods and the wave conditions will show comparable trends as shown in the analysis of the wind forcing data. The more conservative estimates for extreme value analyses could have some benefits for safety-related assessments in offshore engineering for extreme events.

As part of a comprehensive approach to consistently reconstruct atmospheric (Geyer, 2014), tide-surge (Gaslikova and Weisse, 2013) and wind-wave conditions (this paper), the hindcast contributes to a consistent met-ocean data set that provides a useful data source for analysing long-term meteo-marine climate variability and change. Furthermore, it represents a valuable source of data for a large variety of related and more applied research in the industry and administration (Weisse et al., 2015). 
Appendix A: Error metrics

To evaluate the skill of the wave model, standard statistical measures are used. The mean, the standard deviation (SD), the bias, the root mean square error (RMSE), the scatter index (SI) and the correlation coefficient $(r)$ are defined as follows:

mean $=\bar{E}=\frac{\sum_{i=1}^{n} E_{i}}{n}$

$\mathrm{SD}=\sqrt{\frac{\sum_{i=1}^{n}\left(E_{i}-\bar{E}\right)^{2}}{n}}$

$\operatorname{bias}=\frac{\sum_{i=1}^{n}\left(E_{i}-R_{i}\right)}{n}$

$\mathrm{RMSE}=\sqrt{\frac{\sum_{i=1}^{n}\left(E_{i}-R_{i}\right)^{2}}{n}}$

$$
\mathrm{SI}=\frac{\mathrm{RMSE}}{\bar{R}}
$$

$$
r=\frac{\sum_{i=1}^{n}\left(E_{i}-\bar{E}\right)\left(R_{i}-\bar{R}\right)}{\sqrt{\sum_{i=1}^{n}\left(E_{i}-\bar{E}\right)^{2} \sum_{i=1}^{n}\left(R_{i}-\bar{R}\right)^{2}}},
$$

where the overlines indicate mean values over time, $n$ denotes the number of data pairs, $E$ refers to the estimator (coastDat2 or ERA-Interim) and $R$ refers to the reference data (in situ or satellite observations). If coastDat2 is compared to ERA-Interim, the later is used as the reference data $R$. Using the decomposition of the mean squared error $(\mathrm{MSE})$ into variance $(\mathrm{VAR})$ and bias $\left(\mathrm{MSE}=\mathrm{VAR}+\mathrm{bias}^{2}\right)$, the standard deviation of the error (SDE) is used as an estimate for the unbiased RMSE and is defined as

$$
\mathrm{SDE}=\sqrt{\mathrm{RMSE}^{2}-\text { bias }^{2}} .
$$


Appendix B: Available variables

Table B1. List of available variables.

\begin{tabular}{|c|c|c|c|c|}
\hline & Variable name & Unit & Long name & Standard name \\
\hline 2 & ds & degree & total directional spread & sea_surface_wave_directional_spread \\
\hline 4 & ds_swell & degree & swell directional spread & sea_surface_swell_wave_directional_spread \\
\hline 5 & ff & $\mathrm{ms}^{-1}$ & wind speed & wind_speed \\
\hline 6 & $\mathrm{fv}$ & $\mathrm{ms}^{-1}$ & friction velocity & \\
\hline 9 & hs_swell & $\mathrm{m}$ & swell significant wave height & sea_surface_swell_wave_height \\
\hline 10 & nws & none & normalised_wave_stress & normalised_wave_stress \\
\hline 11 & thq & degree & total mean wave direction & sea_surface_wave_to_direction \\
\hline 12 & thq_sea & degree & sea mean wave direction & sea_surface_wind_wave_to_direction \\
\hline 13 & thq_swell & degree & swell mean wave direction & sea_surface_swell_wave_to_direction \\
\hline 16 & tmp_swell & $\mathrm{s}$ & swell mean period & $\begin{array}{l}\text { sea_surface_swell_wave_mean_period_from_variance } \\
\text { _spectral_density_inverse_frequency_moment }\end{array}$ \\
\hline 17 & $\operatorname{tm} 1$ & $\mathrm{~s}$ & total m1-period & $\begin{array}{l}\text { sea_surface_wave_mean_period_from_variance } \\
\text { _spectral_density_first_frequency_moment }\end{array}$ \\
\hline 18 & tm1_sea & $\mathrm{s}$ & sea m1-period & $\begin{array}{l}\text { sea_surface_wind_wave_mean_period_from_variance } \\
\text { _spectral_density_first_frequency_moment }\end{array}$ \\
\hline 19 & tm1_swell & $\mathrm{s}$ & swell m1-period & $\begin{array}{l}\text { sea_surface_swell_wave_mean_period_from_variance } \\
\text { _spectral_density_first_frequency_moment }\end{array}$ \\
\hline 20 & $\operatorname{tm} 2$ & $\mathrm{~s}$ & total m2-period & $\begin{array}{l}\text { sea_surface_wave_mean_period_from_variance } \\
\text { spectral_density_second_frequency_moment }\end{array}$ \\
\hline 21 & tm2_sea & $\mathrm{s}$ & sea m2-period & $\begin{array}{l}\text { sea_surface_wind_wave_mean_period_from_variance } \\
\text { _spectral_density_second_frequency_moment }\end{array}$ \\
\hline
\end{tabular}


Competing interests. The authors declare that they have no conflict of interest.

Acknowledgements. We thank the providers of the observational data, namely, the Bundesamt für Seeschifffahrt und Hydrographie (BSH), the Norwegian Meteorological Institute, the Royal Netherlands Meteorological Institute (KNMI), the European Space Agency (ESA) and the French Research Institute for Exploitation of the Sea (IFREMER) for their support. We also thank the providers of the numerical data - namely, the European Centre for Medium-Range Weather Forecasts (ECMWF) for the ERA-Interim reanalysis data and the Met Office Hadley Centre for Climate Science and Services for access to the sea ice data set.

The article processing charges for this open-access publication were covered by a Research

Centre of the Helmholtz Association.

Edited by: David Carlson

Reviewed by: two anonymous referees

\section{References}

Bertin, X., Prouteau, E., and Letetrel, C.: A significant increase in wave height in the North Atlantic Ocean over the 20th century, Global Planet. Change, 106, 7783,https://doi.org/10.1016/j.gloplacha.2013.03.009, 2013.

Bidlot, J., Janssen, P., and Abdalla, S.: A revised formulation for ocean wave dissipation in CY29R1, ECMWF Technical Memorandum, File: R60.9/JB/0516, 2005.

Bidlot, J., Janssen, P., and Abdalla, S.: A revised formulation for ocean wave dissipation and its model impact, ECMWF Technical Memorandum, 509, ECMWF, Reading, UK, 2007.

Charles, E., Idier, D., Thiébot, J., Cozannet, G. L., Pedreros, R., Ardhuin, F., and Planton, S.: Present Wave Climate in the Bay of Biscay: Spatiotemporal Variability and Trends from 1958 to 2001, J. Climate, 25, 2020-2039, https://doi.org/10.1175/JCLID-11-00086.1, 2012.

Chawla, A., Spindler, D. M., and Tolman, H. L.: Validation of a thirty year wave hindcast using the Climate Forecast System Reanalysis winds, Ocean Model., 70, 189-206, https://doi.org/10.1016/j.ocemod.2012.07.005, 2013.

Cox, A. T. and Swail, V. R.: A global wave hindcast over the period 1958-1997: Validation and climate assessment, J. Geophys. Res.-Oceans, 106, 2313-2329, https://doi.org/10.1029/2001JC000301, 2001.

Dee, D. P., Uppala, S. M., Simmons, A. J., Berrisford, P., Poli, P., Kobayashi, S., Andrae, U., Balmaseda, M. A., Balsamo, G., Bauer, P., Bechtold, P., Beljaars, A. C. M., van de Berg, L., Bidlot, J., Bormann, N., Delsol, C., Dragani, R., Fuentes, M., Geer, A. J., Haimberger, L., Healy, S. B., Hersbach, H., Hólm, E. V., Isaksen, L., Kålberg, P., Köhler, M., Matricardi, M., McNally, A. P., Monge-Sanz, B. M., Morcrette, J.-J., Park, B.-K., Peubey, C., de Rosnay, P., Tavolato, C., Thépaut, J.-N., and Vitart, F.: The ERA-Interim reanalysis: configuration and performance of the data assimilation system, Q. J. Roy. Meteor. Soc., 137, 553-597, https://doi.org/10.1002/qj.828, 2011.
Dodet, G., Bertin, X., and Taborda, R.: Wave climate variability in the North-East Atlantic Ocean over the last six decades, Ocean Model., 31, 120-131, https://doi.org/10.1016/j.ocemod.2009.10.010, 2010.

Feser, F., Weisse, R., and von Storch, H.: Multi-decadal atmospheric modeling for Europe yields multi-purpose data, EOS Transactions, 82, 305-310, 2001.

Gaslikova, L. and Weisse, R.: coastDat-2 TRIM-NP-2d Tide-Surge North Sea, World Data Center for Climate, https://doi.org/10.1594/WDCC/coastDat-2_TRIM-NP-2d, 2013.

Geyer, B.: High-resolution atmospheric reconstruction for $\mathrm{Eu}-$ rope 1948-2012: coastDat2, Earth Syst. Sci. Data, 6, 147-164, https://doi.org/10.5194/essd-6-147-2014, 2014.

Geyer, B., Weisse, R., Bisling, P., and Winterfeldt, J.: Climatology of North Sea wind energy derived from a model hindcast for 1958-2012, J. Wind Eng. Ind. Aerod., 147, 18-29, https://doi.org/10.1016/j.jweia.2015.09.005, 2015.

Groll, N. and Weisse, R.: coastDat-2 North Sea wave hindcast for the period 1949-2014 performed with the wave model WAM, World Data Center for Climate, https://doi.org/10.1594/WDCC/coastDat-2_WAM-North_Sea, 2016.

Holthuijsen, L. H.: Waves in oceanic and coastal waters, Cambridge University Press, 2007.

Kalnay, E., Kanamitsu, M., Kistler, R., Collins, W., Deaven, D., Gandin, L., Iredell, M., Saha, S., White, G., Woollen, J., Zhu, Y., Leetmaa, A., Reynolds, R., Chelliah, M., Ebisuzaki, W., Higgins, W., Janowiak, J., Mo, K. C., Ropelewski, C., Wang, J., Jenne, R., and Joseph, D.: The NCEP/NCAR 40-Year Reanalysis Project, B. Am. Meteorol. Soc., 77, 437-471, https://doi.org/10.1175/15200477(1996)077<0437:TNYRP>2.0.CO;2, 1996.

Kettle, A. J.: Review Article: Storm Britta in 2006: offshore damage and large waves in the North Sea, Nat. Hazards Earth Syst. Sci. Discuss., https://doi.org/10.5194/nhessd-3-5493-2015, in review, 2015.

Kistler, R., Collins, W., Saha, S., White, G., Woollen, J., Kalnay, E., Chelliah, M., Ebisuzaki, W., Kanamitsu, M., Kousky, V., van den Dool, H., Jenne, R., and Fiorino, M.: The NCEP-NCAR 50-Year Reanalysis: Monthly Means CD-ROM and Documentation, B. Am. Meteorol. Soc., 82, 247-267, https://doi.org/10.1175/15200477(2001)082<0247:TNNYRM>2.3.CO;2, 2001.

Komen, G., Cavaleri, L., Hasselmann, H., Hasselmann, S., and Janssen, P.: Dynamics and Modelling of Ocean Waves, Cambridge University Press, 1996.

Neumann, D., Matthias, V., Bieser, J., Aulinger, A., and Quante, M.: A comparison of sea salt emission parameterizations in northwestern Europe using a chemistry transport model setup, Atmos. Chem. Phys., 16, 9905-9933, https://doi.org/10.5194/acp16-9905-2016, 2016.

Ponce de León, S. and Guedes Soares, C.: Hindcast of extreme sea states in North Atlantic extratropical storms, Ocean Dynam., 65, 241-254, https://doi.org/10.1007/s10236-014-0794-6, 2015.

Queffeulou, P.: Merged altimeter wave height data base. An update, in: ESA Living Planet Symposium 2013, Edinburgh, UK, 9-13 September 2013, ESA SP-722, available at: ftp://ftp.ifremer.fr/ifremer/cersat/products/swath/altimeters/ waves/documentation/publications/ESA_Living_Planet_ Symposium_2013.pdf, 2013. 
Rayner, N. A., Parker, D. E., Horton, E. B., Folland, C. K., Alexander, L. V., Rowell, D. P., Kent, E. C., and Kaplan, A.: Global analyses of sea surface temperature, sea ice, and night marine air temperature since the late nineteenth century, J. Geophys. Res.-Atmos., 108, 4407, https://doi.org/10.1029/2002JD002670, 2003.

Reguero, B., Menéndez, M., Méndez, F., Mínguez, R., and Losada, I.: A Global Ocean Wave (GOW) calibrated reanalysis from 1948 onwards, Coast. Eng., 65, 38-55, https://doi.org/10.1016/j.coastaleng.2012.03.003, 2012.

Reguero, B., Méndez, F., and Losada, I.: Variability of multivariate wave climate in Latin America and the Caribbean, Global Planet. Change, 100, 70-84, https://doi.org/10.1016/j.gloplacha.2012.09.005, 2013.

Reistad, M., Breivik, O., Haakenstad, H., Aarnes, O. J., Furevik, B. R., and Bidlot, J.-R.: A high-resolution hindcast of wind and waves for the North Sea, the Norwegian Sea, and the Barents Sea, J. Geophys. Res.-Oceans, 116, c05019, https://doi.org/10.1029/2010JC006402, 2011.

Rockel, B., Will, A., and Hense, A.: The Regional Climate Model COSMO-CLM (CCLM), Meteorol. Z., 17, 347-348, 2008.

Schwichtenberg, F., Callies, U., Groll, N., and Maßmann, S.: Effects of chemical dispersants on oil spill drift paths in the German Bight-probabilistic assessment based on numerical ensemble simulations, Geo-Mar. Lett., 37, 163-170, https://doi.org/10.1007/s00367-016-0454-6, 2017.

Sterl, A., Komen, G. J., and Cotton, P. D.: Fifteen years of global wave hindcasts using winds from the European Centre for Medium-Range Weather Forecasts reanalysis: Validating the reanalyzed winds and assessing the wave climate, J. Geophys. Res.-Oceans, 103, 5477-5492, https://doi.org/10.1029/97JC03431, 1998.

Uppala, S. M., KÅllberg, P. W., Simmons, A. J., Andrae, U., Bechtold, V. D. C., Fiorino, M., Gibson, J. K., Haseler, J., Hernandez, A., Kelly, G. A., Li, X., Onogi, K., Saarinen, S., Sokka, N., Allan, R. P., Andersson, E., Arpe, K., Balmaseda, M. A., Beljaars, A. C. M., Berg, L. V. D., Bidlot, J., Bormann, N., Caires, S., Chevallier, F., Dethof, A., Dragosavac, M., Fisher, M., Fuentes, M., Hagemann, S., Hólm, E., Hoskins, B. J., Isaksen, L., Janssen, P. A. E. M., Jenne, R., Mcnally, A. P., Mahfouf, J.-F., Morcrette, J.-J., Rayner, N. A., Saunders, R. W., Simon, P., Sterl, A., Trenberth, K. E., Untch, A., Vasiljevic, D., Viterbo, P., and Woollen, J.: The ERA-40 re-analysis, Q. J. Roy. Meteor. Soc., 131, 29613012, https://doi.org/10.1256/qj.04.176, 2005. von Storch, H., Langenberg, H., and Feser, F.: A Spectral Nudging Technique for Dynamical Downscaling Purposes, Mon. Weather Rev., 128, 3664-3673, https://doi.org/10.1175/15200493(2000)128<3664:ASNTFD>2.0.CO;2, 2000.

WAMDI-Group: The WAM model - a third generation ocean wave prediction model, J. Phys. Oceanogr., 18, 1776-1810, 1988.

WASA-Group: Changing Waves and Storms in the Northeast Atlantic?, B. Am. Meteorol. Soc., 79, 741-760, https://doi.org/10.1175/15200477(1998)079<0741:CWASIT>2.0.CO;2, 1998.

Weisse, R. and Günther, H.: Wave climate and long-term changes for Southern North Sea obtained from a highresolution hindcast 1958-2002, Ocean Dynam., 57, 161-172, https://doi.org/10.1007/s10236-006-0094-x, 2007.

Weisse, R. and Plüss, A.: Storm-related sea level variations along the North Sea coast as simulated by a highresolution model 1958-2002, Ocean Dynam., 56, 16-25, https://doi.org/10.1007/s10236-005-0037-y, 2006.

Weisse, R., von Storch, H., Callies, U., Chrastansky, A., Feser, F., Grabemann, I., Günther, H., A. Plüss, T. S., Tellkamp, J., Winterfeldt, J., and Woth, K.: Regional meteorologicalmarine reanalysis and climate change projections. Results for northern Europe and potential for coastal and offshore applications, B. Am. Meteorol. Soc., 90, 849-860, https://doi.org/10.1175/2008BAMS2713.1, 2009.

Weisse, R., Bisling, P., Gaslikova, L., Geyer, B., Groll, N., Hortamani, M., Matthias, V., Maneke, M., Meinke, I., Meyer, E. M., Schwichtenberg, F., Stempinski, F., Wiese, F., and WöcknerKluwe, K.: Climate services for marine applications in Europe, Earth Perspectives, 2, 1-14, https://doi.org/10.1186/s40322-0150029-0, 2015. 